\title{
Kirjaesineen monista materiaalisuuksista
}

\begin{abstract}
Kaisa Ahvenjärvi, Juri Joensuu, Anna Helle \& Sanna Karkulehto (toim.): Paperinen avaruus: Näkökulmia kirjaesineen ja kirjallisuuden materiaalisuuksiin. Jyväskylän yliopisto: Nykykulttuurin tutkimuskeskuksen julkaisuja 128, 2020, 373 s.
\end{abstract}

Ihminen on historian aikana luonut kirjoitukseksi tulkittavissa olevia merkkejä muun muassa puuhun, kaarnaan, luihin, kiviin, metalliin, palmunlehviin, saveen, kankaisiin, nahkaan, kaisloille, sekä vajaan parin tuhannen vuoden ajan myös paperille. Näistä eri materiaaleista on koostettu kirjan kaltaisia esineitä useamman vuosituhannen ajan, lähtien mesopotamialaisista savitaululaatikoista, egyptiläisistä papyrusrullista tai vaikkapa kiinalaisista yhteen sidotuista bambuliuskoista. Codex-termillä ryhdyttiin kutsumaan ajanlaskumme alkuvuosisatoina kirjamuotoa, jossa useampi, tavallisesti nahasta parkittu lehti oli sidottu yhteen.

Kirjan esihistoria kaikessa kirjavuudessaan olisi hyvä ottaa huomioon, kun tarkastellaan kirjaesinettä ja sen materiaalisuuksia. Nykykulttuurin tutkimussarjassa ilmestynyt Paperinen avaruus: Näkökulmia kirjaesineen ja kirjallisuuden materiaalisuuksiin -kokoomateos keskittyy kuitenkin vain (jälki)gutenbergilaiseen traditioon eikä viittaa siihen, miten tuntemamme kirjaesine on alkujaan kehittynyt tai mitä muita kirjoituskoosteita Euroopan ulkopuolella on kehitetty. Tästä huolimatta Paperinen avaruus on erinomainen artikkelikokoelma. Ajankohtaiseksi sen tekee sähköisen kirjallisuuden aiheuttama vastareaktio, jossa on alettu kiinnittää huomiota siihen, minkä jotkut ovat jo ajatelleen olevan katoamassa: kirjaan materiaalisena esineenä.

Kokoelma on toimitettu Jyväskylän kirjallisuuden professorin Mikko Keskisen juhlapäivän kunniaksi. Juhlakirjaksi teos on teemoiltaan harvinaisen hyvin koossa pysyvä, mutta samalla artikkelien muodoltaan ilahduttavan monipuolinen sommitelma. Mukana on paitsi vertaisarvioituja artikkeleita, myös vapaammin kirjoitettuja esseitä sekä eri tavoin kirjoituksen materiaalisuutta hyväksikäyttäviä runoja.

Ajallisesti vanhimmasta kirjaesineestä kirjoittaa Urpo Kovala, jonka artikkeli käsittelee Pälkäneen aapista, isonvihan aikana tehtyä kirjasta, jonka painolaatat oli kaiverrettu puulaatalle. Yhtään kappaletta siitä ei ole säilynyt, mutta tarina on elänyt sukupolvien yli. Artikkeli toimii hyvänä muistutuksena kirjallisuuden reunaehdoista: lukutaidon, yhteiskunnallisten olojen ja teknisen kekseliäisyyden merkityksestä kirjojen synnylle.

Materiaalisuutta hyödyntäviä tai sitä laajentavia kirjaesineitä esittelevät Raine Koskimaan essee hybridikirjoista ja Heta Marttisen artikkeli lasten kur- 
kistuskirjasta, Oskari Rantala taas analysoi oman genrensä materiaalisuudella leikkivää sarjakuvateosta The League of Extraordinary Gentlemen.

Kirjallisuuden avantgarden tapoja hyödyntää kirjan materiaalisuutta taas analysoivat Juha-Pekka Kilpiö ja Juri Joensuu. Kilpiön artikkeli Raisa Marjamäen pitkälle käsityönä toteuttamasta Ei kenenkään laiturissa -teoksesta avaa mielenkiintoisia näkymiä paitsi Marjamäen teokseen myös yleisemmin kirjan rakenteen, painotekniikan, tekstin asemoinnin ja aleatorisuuden kysymyksiin. Joensuu taas esittelee kirjallista tuhontaa, jossa kirjoitusta ylipyyhitään, sitä leikellään ja järjestetään uudelleen, tai itse kirjaesinettä pahoinpidellään esimerkiksi poraamalla siihen reikiä. Kummatkin artikkelit esittelevät tapoja, joilla kokeellinen kirjallisuus on irtaantunut perinteisen codex-mallisen kirjan formaatista ja tehnyt kirjan materiaalisuuksista osan omaa merkityksenmuodostustaan.

Laura Piippo taas kiinnittää huomion marginaaleihin, niin termin konkreettisessa, tekstin asemointiin liittyvässä kuin abstraktimmassa, valtadiskurssien reunamiin viittaavassa merkityksessä. Lyhyeen tilaan Piippo on saanut mahdutettua paljon oivaltavia huomioita materiaalisuuden, tekstuaalisuuden ja valtasuhteiden yhteyksistä.

Kokoelman neljäs osa irtautuu jossain määrin kirjaesineen teemoista, vaikka materiaalisuuksien parissa enimmäkseen liikutaan. "Ihmiselon kirjuus ja kertomuksentutkimuksen parsainen käänne" -hupailun viidellä kirjoittajalla on selvästikin ollut hauskaa.

Maria Mäkelä sen sijaan tähtää aikamme kulttuurisiin kipupisteisiin. Kertomakirjallisuus on Mäkelän mukaan sopeutunut osaksi myöhäiskapitalistista tarinataloutta. Niin somessa leviävät kuin markkinoijien myymät tunteisiin vetoavat kertomukset korostavat uusliberalistisesti yksilön kykyä selviytyä vaikeuksista. Mäkelä väittää, että taiteen ja humanismin jouduttua puolustuskannalle myös kirjallisuusinstituutio on ryhtynyt vetoamaan kirjallisuuden välinearvoihin, esimerkiksi korostamalla kirjallisuuden empatiaa ja eettistä ajattelua edistävää luonnetta, ja siten mukautunut osaksi self-help -kulttuuria.

Mäkelä kritisoi kirjallisuuden välineellistymistä: vetoaminen kirjallisuuden välinearvoon kaventaa kirjallisuuskäsitystämme, luo kuvaa, että ollakseen hyvää kirjallisuuden pitää olla yksilöä voimaannuttavaa tai empatiaa kehittävää. Mutta voi myös kysyä, miksi kirjallisuuteen ei saisi joissain tapauksissa suhtautua välineellisesti? Esimerkiksi kirjallisuusterapiassa tekstejä lähestytään terapian välineinä, ja toisin kuin Mäkelän mainitsemat tutkimukset kirjallisuuden empatiaa lisäävästä arvosta, kirjallisuusterapian toimivuuden vahvistaneet tutkimukset ovat saaneet tutkimusyhteisössä taakseen vankan konsensuksen. Tekstin terapeuttinen käyttö tuskin tekee siitä sen parempaa tai huonompaa kirjallisuutta, mutta voi helpottaa yksilön kärsimystä.

Joonas Säntti tarkastelee Anu Kaajan romaania Leda ja perustelee vakuuttavasti, miten sen sisältämät, kerronnan perinteisiä konventioita rikkovat metalepsikset ovat tiiviisti kytköksissä sen queer-poliittiseen sisältöön. Hieman 
vaikeaa sen sijaan on suhtautua Tiina Katriina Kukkosen artikkeliin Aleksis Kiven Seitsemän veljeksen geometrisesta ajattelusta - niin tärkeää kuin sommittelu ja tilallinen ajattelu ovatkin romaanigenrelle, tuntuvat Kukkosen esimerkit Kiven ympyrä- ja neliömuodoista ja niiden yhteydestä Leon Battista Albertin teksteihin hieman väkinäisiltä ja kaukaa haetuilta.

Paperista avaruutta kehystää joukko vapaamuotoisempia esseitä ja runoja. Leena Kirstinä aloittaa kirjan analysoimalla edesmenneeltä puolisoltaan, kirjailija Väinö Kirstinältä jäänyttä muistikirjaa, Keijo Virtasen ja Mika Hallilan persoonalliset esseet kirjoittamisesta ja kirjoista taas päättävät kirjan. Kari Rummukainen esittelee omassa kirjallista appropriaatiota hyödyntävässä tekstikoosteessaan sellaisia kirjallisuuden "klassikoita" kuin Joel Carlsonin Mutsien asianajaja, Martin Heideggerin Melominen ja aika sekä Tuure Junnilan Kanoottikriisi. Suvi Vallin, Raisa Marjamäen ja Harry Salmenniemen runot taas juhlivat kukin omalla tavallaan kirjoituksen visuaalisuutta.

Onkin syytä onnitella paitsi tasavuosia täyttänyttä Mikko Keskistä myös kirjan toimittajia, Kaisa Ahvenjärveä, Juri Joensuuta, Anna Hellettä ja Sanna Karkulehtoa monipuolisesta ja hyvin toimitetusta kokonaisuudesta.

Kuisma Korhonen 